the relationship in control neonates or older children. In the face of low cord blood (-LDI., nearly all of the total plasma cholesterol variation was accounted for by (-HDI. The inverse (HDL to C-I.DI correlation was not significant.

In hyperalphalipoproteinemic neonates. (-L.DI. but not (HDI. correlated significantly with total plasma cholesterol. Nearly all of the total plasma cholesterol variation was accounted for by (-I.I)I. The inverse (-HD) to (-I.DI. relationship was not significant.

Whatever factors contribute to both the overall and to the extremes of the (-HDI and (-L.DI. frequency distributions at hirth. ('-HDI. and ('-I.DI. in neonates appear to be under independent metabolic control.

It might be interesting to follow into later infancy and childhood neonates at the extreme of the (-I.D) and (-11D) d distributions to determine whether or when. with the inevitable ascendence of (-LDI as the predominant cholesterol carrying lipoprotein $(1-4)$, significant inverse (-HD) to ('-I.DI. relationships will appciar.

\section{(O)N(I.USIO)N}

In 117 unselected neonates the correlation coefficients for (HDI to total cholesterol $(r=0.6 .3)$, and (-I.DI to total cholesterol $(r=0.76)$ were very similar to those reported for older children. However, in contrast to school children, the (-HDI. to (-1.DI, relationship in the unselected neonates was not significant $(r=-0.002)$. In 6.3 hypobetalipoproteinemic neonates, (I.DI failed to correlate with total plasma cholesterol levels $(r-$ $0.07)$, but (-HDL was closely related to total cholesterol $(r=$ 0.98). The inverse (-HDL to (-L.DL correlation was not significant. In 58 hyperalphalipoproteinemic neonates (-I.D) $(r=$ $0.88)$, but not ( - HDL,$(r=0.22)$, correlated significantly with total plasma cholesterol. Nearly all of the total plasma cholesterol variation was accounted for by (-I.D). The inverse ('HDL to (-L.DL relationship $(r=-0.18)$ was not significant. Whatever factors contribute to both the overall and to the extremes of the (-HDI. and C-L.DI. frequency distributions at birth. C-HDL and (-LDL in neonates appear to be under independent metabolic control.
RIEFIRI:N(TS AND NOTI:S

1. Carlson, I., A.: L ipoprotein fractionation. J. Clin. Path. Suppl. 5. 20: 32 (1973).

2. Fredrickson, D. S., and I.evy, R. I.: Familial hyperlipoproteinemia In: J. B. Stanhury. J. B. Wyngaarden, and D. S. Fredrickent The Metaholic Basis of Inherited Discance, I:d. 3, pp. 545-614(Mc(iralw-Hill Book ('o., New York. $1972)$

3. Cilueck. ( . J : Alpha-lipoprotein cholesterol, beta-lipoprotein cholesterol. and longevity. Artery. 2(3): $196(1976)$

4. Cilueck, (. J., Ciartside, P., Fallat, R. W. Siclski, I., and Stciner, P. M. longevity syndromes: Familial hypobeta- and fitmilial hyperalphatipopro-

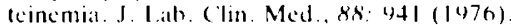

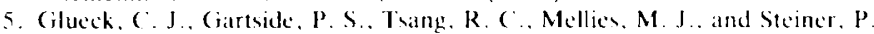
M.: Black-white similarties in cord blood lipids and lipoprotein. Metaher lism. 26: 347 (1977).

6. Glueck, (. J. Tsang, R. ( . Mellier, M. J. and Steiner. P. M.: Neonatal familial hyperalphat-lipoproteinemiat. Metaholism, 26: 469 (1977).

7. Nichols. A. V.: Human serum lipoprotein and their relationships. Advan. Biol. Med. Phys., 11: 109 (1967).

x. Nikkilat, F.: Studies on lipid-protein relationships in normal and pathological sera and effect of he parin on serum lipeproteins. Scand. J. (lin. 1.atb. Invest. Suppl. 5: 1 (105.3)

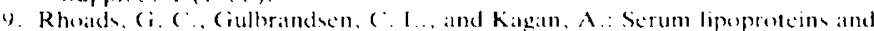
coronary heart disease in a population survey of Hawaii-Japanese men. New Fingl. J. Med. 294: 293 (1976)

10. Snedecor, (i. W. and cochran. If. (i.: Statistical Methods, lid. h. p. Se (Iowa State college Pres. Ames. Iowas. 1967).

11. Snedecor, (i. W. and Cochran. W. G.: Statistical Methods, 1.d. 6. p. 135 llowa State (i)llege Press. Ames, lowal. 1967).

12. Srimivatan, S. R.. Frerichs, R. R., Webher. I. S.. and Berenson, (i. S : Serum lipoprotein profile in children from a biracial community. Circulation, 54: $3(1)(1976)$.

13. Tsang. R. (... Fallatt. R. W.. and (ilueck. ( . J.: ( holesterol at hirth and age : (omparion of normal and hypercholesterolemic neonates. Pediatrics. 53 : $4.58(1974)$

14. Tsang, R. ('.. and (ilueck. ('. J.: Perinatal cholesterol metaho)lism. In: I.. A. Barness, and R. M. Pitkin: (linice in Perinatology. Vol. 2, No. 2. pp. 275295 (WW. B. Satunders ( 6. . Philadelphia. 1975).

15. Tsing. R. Cilueck. C. J.. Fvam. (i... and Steiner. P. M.: (Cord hlosed hypertriglyceridemiat Amer. J. Dis. (child.. 127:78 (1974).

16. Tsang, R. ( . (ilueck. ( . J., Fallat, R. W. and Mellies, M. J.: Neonattal familitt hypercholesterolemia. Amer. J. D)is. (hild. 129:83 (1975)

17. A portion of this worh was supported by the (icneral (linical Reneareh center. RR 0o(o6x-14 and at portion was done during Dr. (iluecks tenure as an Fstahlished Investigitor of the American Heart Association. 1971-1976.

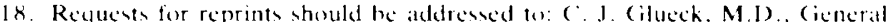
Clinical Research (enter. Concinnati (ieneral Hespital. 234 cierodman St.. $\mathrm{Rm}$. ( $2-3$. ('incinnati. ()hio 45267 (USA)

19. Received for publication December 20.1976 .

20. Accepted for publication Fibruary 9.1977.
Extrauterine life gestational age glomerular filtration rate inulin clearance

\title{
Glomerular Filtration Rate during the Period of Adaptation to Extrauterine Life
}

\author{
ROSIMARY D. I.LAKL:": ANI) ('ARI, W. TRY(ISTAD) \\ Department of Pediatrics, UC L.A School of Medicine. Harbor Cieneral Hespital, Torrance. California, USA
}

\begin{abstract}
Summary
Inulin clearance $\left(C_{i, 1}\right)$ was measured in 20 infants of $27-43$ weeks of gestation during the first $24 \mathrm{hr}$ of their extrauterine life. $C_{i \prime \prime}$ ranged from $0.7-4.7 \mathrm{ml} / \mathrm{min}$ and correlated with gestational age $(P \quad 0.05)$. In 18 infants of similar gestational ages studied after 2-3 days of extrauterine adaptation, the $C_{i+1}$ ranged from
\end{abstract}

1.1-17.9 $\mathrm{ml} / \mathrm{min}$ and also correlated with gestational age $(P$. 0.01). By day 2-3, the infants of near term gestational age achieved a greater increase in $\mathrm{C}_{\mathrm{in}}$ than did the markedly preterm infants, as reflected by a significantly different slope of the regression line for $C_{i 11}$ and gestational age for the infants studied at 1 vs. $2-3$ days of age $(P=0.001)$. 


\section{Speculation}

Although gestational age does affect glomerular filtration rate (GFR) in the first day of life, additional factors influencing glomerular filtration rate during this period may be adjustments in extrarenal hemodynamics, renal blood flow, and extracellular volume. We have shown previously that high rates of infusion of fluid result in an increase in glomerular filtration rate in the preterm infant. It is possible that the limitation noted in glomerular filtration rate during the first few days of life is partly related to decreasing extracellular fluid.

The exteriorized lamb has been used as a model to study function of the mammalian metanephric kidncy. Rohillard et al. (11) reported a direct correlation between fetal lamb glomerular filtration rate and gestational age. Alexander and Nixon (1) reported in utero inulin clearances $\left(C_{\text {int }}\right)$ of 0.4 and $1.7 \mathrm{ml} / \mathrm{min}$ in lamb fetuses of 89-119 and 121-140 days, respectively (1). By full term, fetal lambs achieved a $C_{\text {in }}$ of $4.3 \mathrm{ml} / \mathrm{min}$; by 1 day of age their $C_{\text {in }}$ doubled to $9 \mathrm{ml} / \mathrm{min}$.

Oh et al. (10) have described a $C_{\text {in }}$ of $20 \mathrm{ml} / \mathrm{min} / 1.73 \mathrm{~m}^{2}$ for healthy, 1-12-hr-old infants of $38-42$ weeks gestation. When measured at 2-3 days of age. $C_{i n}$ is proportional to gestational age and to conceptual age (gestational age and postnatal age) when measured during the first months of life (8). Few data are available. however, for the $C_{\text {in }}$ of premature infants during the first day of life (5). Thus. during this period. fluids, electrolytes, and drugs excreted by glomerular filtration have been administered in an empiric manner.

This study reports the $C_{\text {in }}$ of infants of various gestational ages during the first day of extrauterine life. The data are compared to 18 infants studied 2-3 days after birth at a time when postnatal hemodynamic adjustment would have been largely accomplished.

\section{MATERIALS AND MEIHIODS}

The study protocol was approved by the Harbor General Hospital Human Subjects Committec. After obtaining informed parental consent. 20 healthy appropriate for gestational age newborn infants less than 24 hr of age were selected for study. Birth weight ranged from 580 to $3500 \mathrm{~g}$ (Table 1). Fighteen similar, 2-3-day-old infants were studied in an identical manner
(Table 2). Thirty-one infants had received glucose at a rate of 6 $\mathrm{mg} / \mathrm{kg} / \mathrm{min}$ from birth; seven infants were receiving milk-based formula (1-2 ounces every $+\mathrm{hr})$.

The studies were performed with the infant having fasted for at least $3 \mathrm{hr}$. An intravenous solution of dextrose water was administered at a rate of $6 \mathrm{mg} / \mathrm{kg} / \mathrm{min}$. A baseline serum inulin concentration was obtained. A priming dose of $5, \mathrm{mg} / \mathrm{kg}$ body weight of inulin. 10\% solution, (purified inulin solution. StoneArnar Company, Mt. Prospect, Ill.) was infused intravenously over a 1 -min period. A sustaining dose of $0.1 \mathrm{mg} / \mathrm{kg} / \mathrm{min}$ inulin and glucose was administered by means of a constant infusion pump for 1-.3 hr using a mixture of $0.13 \%$ inulin and $5 \%$ glucose.

Serial inulin samples were obtained by heel puncture every $30-60 \mathrm{~min}$ and at the time of each voiding. The infusate concentration of inulin was measured and the pump infusion speed was determined at appropriate intervals. All infants included in the study achieved steady plasma inulin levels. Inulin determinations were performed by the resorcinol method (12). A standard curve for inulin. $5 \%$ glucose. and serum blank were run with each determination.

The inulin clearance was calculated on the basis of a constant infusion principle $(2,8,9)$ with the following formulat

$$
\text { Inulin clearance }=\text { inulin concentration in infusite }(\mathrm{mg} / \mathrm{ml})
$$$$
\times \text { rate of inulin infusion }(\mathrm{ml} / \mathrm{min})
$$

$$
\text { plasma inulin }(\mathrm{mg} / \mathrm{ml})
$$

\section{RESULTS}

Ciestational ages, determined by menstrual history and by Dubowitz scoring ( 4 ), varied from $27-43$ weeks (Table 1 ). Mean postnatal age at study was $17 \mathrm{hr}$ for the 20 infants studied carly. The 18 infants studied at 2-3 days of life were of similar gestational ages and weights (Table 2); mean age at study was $74 \mathrm{hr}$

All infants were healthy at the time of study except for three patients with mild meconium aspiration and two with mild respiratory distress syndrome. None required ventilatory assistance.

Table I shows the data for the individual infants less than 24 hr of age. Inulin clearance $\left(C_{i n}\right)$ for these infants ranged from $0.7-4.7 \mathrm{ml} / \mathrm{min}$. The $C_{\text {in }}$ for the infants studied at 2-3 days of age, seen in Table 2, ranged from 1.1 to $17.9 \mathrm{ml} / \mathrm{min}$. Figure 1 shows that $C_{\text {in }}$ measured at less than $24 \mathrm{hr}$ of age and at 2-3 days

Table 1. Inulin clearance in first $24 \mathrm{hr}$

$\begin{array}{cl}\text { Patient } & \text { Condition at study } \\ 1 & \text { Healthy } \\ 2 & \text { Healthy } \\ 3 & \text { Healthy } \\ 4 & \text { Mild meconium aspiration } \\ 5 & \text { Healthy } \\ 6 & \text { Healthy } \\ 7 & \text { Healthy } \\ 8 & \text { Healthy } \\ 9 & \text { Healthy } \\ 10 & \text { Healthy } \\ 11 & \text { Mild meconium aspiration } \\ 12 & \text { Healthy } \\ 13 & \text { Mild respiratory distress syndrome } \\ 14 & \text { Healthy } \\ 15 & \text { Healthy } \\ 16 & \text { Healthy } \\ 17 & \text { Healthy } \\ 18 & \text { Healthy } \\ 19 & \text { Healthy } \\ 20 & \text { Healthy }\end{array}$

$\begin{array}{cc}\text { Gestational age. weeks } & \text { Birth wt. g } \\ 27 & 580 \\ 29 & 800 \\ 38 & 2800 \\ 43 & 2600 \\ 28 & 885 \\ 34 & 1760 \\ 27 & 990 \\ 30 & 710 \\ 30 & 975 \\ 41 & 3500 \\ 41 & 3470 \\ 41 & 2810 \\ 30 & 1180 \\ 34 & 2320 \\ 38 & 2520 \\ 38 & 2520 \\ 33 & 1760 \\ 35 & 2183 \\ 39 & 2300 \\ 35 & 1985\end{array}$

Age at study, hr
24
22
19
12
19
20
12
18
18
24
22
19
17
18
2
24
18
16
7
15

$C_{m, n} \mathrm{ml} / \mathrm{min}$
0.8
1.6
4.7
3.2
1.4
0.7
1.6
0.9
1.1
3.9
2.7
2.8
2.0
4.1
1.1
1.0
0.7
0.9
1.3
1.6


Table 2. Inulin clearance at age 2-3 days

$\begin{array}{cl}\text { Patient } & \text { Condition at study } \\ 1 & \text { Healthy } \\ 2 & \text { Healthy } \\ 3 & \text { Healthy } \\ 4 & \text { Healthy } \\ 5 & \text { Healthy } \\ 6 & \text { Healthy } \\ 7 & \text { Healthy } \\ 8 & \text { Healthy } \\ 9 & \text { Healthy } \\ 10 & \text { Healthy } \\ 11 & \text { Healthy } \\ 12 & \text { Mild meconium aspiration } \\ 13 & \text { Healthy } \\ 14 & \text { Mild respiratory distress syndrome } \\ 15 & \text { Healthy } \\ 16 & \text { Healthy } \\ 17 & \text { Healthy } \\ 18 & \text { Healthy }\end{array}$

Mean \pm SF $: M$

was proportional to gestational age $(P<0.05)$. The slope of the regression line for infants less than 24 hr of age was significantly different from that for infants of similar gestational age studice at 2-3 days of age $(P<0.001)$. There was a significant difference between $C_{i n}$ in the first $24 \mathrm{hr}$ of life in the preterm $(<37$ wecks) and full term infants (mean $=1.5 \mathrm{vs} .2 .6 \mathrm{ml} / \mathrm{min} ; P$ (). (0) 5 .

\section{DISC USSION}

Neonatal adaptations influencing renal function occurring at the time the fetus begins extrauterine life include dramatic sequential changes in blond pressure. vascular resistance, and blood flow. These are accompanied by changes in body fluid composition. Extracellular water decreases from $45 \%$ to approximately 39\%; of hody weight by 7 days of age (7). In addition. the degree of placental transfusion. the presence or absence of a patent ductus arteriosus diverting hlood from the kidney, and varying colloid osmotic pressures may also influence renal function during the first day of life. Thus, measurements of GFR during the first day of life at any gestational age may reflect a transitory state of renal function in which the major influences may be adaptive processes rather than total glomerular functional potential.

The GFR as reflected by the $C_{i n}$ is proportional to gestational age when measured either in the first 24 hr or at $2-3$ days. In addition, the inulin clearance measured after 2-3 days is proportional to conceptual age (8). In the infants studicd at 2-3 days. $C_{i n}$ may more nearly reflect actual renal maturation rather than the functional changes oceurring during the first few days following birth. This concept is supported hy the fact that the functional acceleration in $C_{\text {in }}$ secen over the first few days of life is greater in infants of greater gestational age who presumably have more mature kidneys.

Although the data from this study are similar to the values reported by Guignard (5) for four infants on the first daty of life, this series represents the first report of inulin slearance for the markedly preterm infants of kess than $24 \mathrm{hr}$ of age. Values for the premature infants in this series are significantly lower than those previously reported in full term subjects less than $2+\mathrm{hr}$ of age (10). This may represent an anatomic limitation to renal function since the full glomerular complement is not present until after 36 weeks' gestation. It is likely that the hemodynamic and body composition changes occurring over the first few days also affect glomerular filtration. In contrast to the values presented here for our basically healthy infants. inulin clearance is

$\begin{array}{cc}30 & \text { Birth wt.g } \\ 30 & 1070 \\ 41 & 3740 \\ 34 & 1570 \\ 34 & 1340 \\ 32 & 1420 \\ 38 & 3000 \\ 29 & 1080 \\ 34 & 1928 \\ 40 & 3500 \\ 34 & 1710 \\ 30 & 1160 \\ 42 & 2800 \\ 29 & 1130 \\ 27 & 1050 \\ 34 & 1820 \\ 40 & 3280 \\ 38 & 3005 \\ 40 & 2620 \\ 34+1.1 & 2069+221\end{array}$

Days at study

$C_{\mathrm{i}, \mathrm{ml}} \mathrm{ml} / \mathrm{min}$

2.5

17.9

2.6

2.5

3.5

8. 1

2.5

4.7

6.0

3.4

2.4

7.4

1.1

1.3

2.5

). 1

3.7

6.3

$4.9 \pm 0.9$

markedly reduced by various pathologic processes common in sick preterm infants $(3.6)$.

Figure I shows the inulin clearance data as a function of gestational age. The direct implications of this study are that renal function is proportional to gestational age in infants before and after a period of extrauterine adaptation. There is also a significant difference between the inulin clearance of the preterm and the full term infants. Furthermore, the absolute magnitude of the adaptive increase in CiFR over the first few days of extrauterine life is greater in term infants than in preterm infants.

Our data support the concept that the dosage for substances excreted by glomerular filtration should. during the first day of life, be calculated utilizing the volume of drug distribution predominantly. After 2-3 days of age a correction should be made for changes in glomerular filtration rate related to gestational age.

\section{(}

The inulin clearance rates $(C{ })$ of 38 infants varying in gestational age from 27-4.3 wecks were studied at less than 24 hr of age or 2-3 days of age. Inulin clearance varicd from $0.7-4.7 \mathrm{ml} /$ min in the younger infants and $1.1-17.9 \mathrm{ml} / \mathrm{min}$ in the older

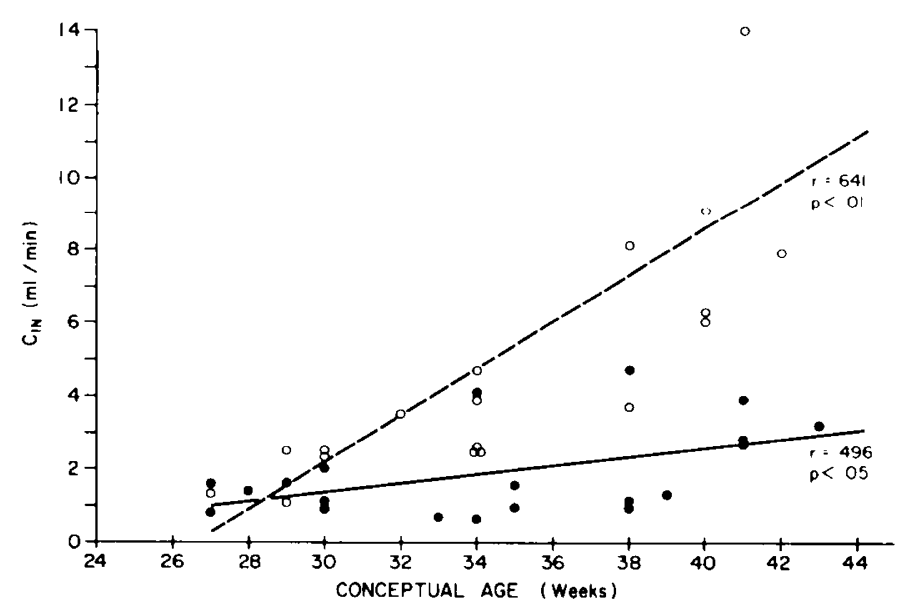

Fig. 1. Insulin clearance of infants studicd at less than 24 hr $(-)$ and at 2-.3 days of age (- - ). Intants $2-3$ days of age: $C_{\text {in }}=2.2+0.1187 \times$ age. Infants 24 hr of age: $C_{i n}=17.36+0.6406 \times$ age. 
infants. During both study periods inulin clearance was proportional to gestational age. The slopes of the regression lines for $C_{\text {in }}$ vs. gestational age were significantly different. The absolute increases in $C_{\text {in }}$ following $2-3$ days of extratuterine adaptation were greater for the near term infants than for the markedly preterm ones.

\section{REFERENCIS AND NOTES}

1. Alexander. D. P.. and Nixon. D. A.: Plasma clearance of P-amino-hippuric acid by the kidneys of fetal. neonatal and adult sheep. Nature. 194: 48.3 (1962).

2. Cole, B. R.. Giangiacomo, J., Ingelfinger. J.. and Rohson. A .: Measurement of renal function without urine collection. N. Engl. J. Med., 287: 1109 (1972).

3. Dauber. 1. M.. Krauss, A. N.. Symchych, P. S.. and Auld, P. A. M.: Renal failure following perinatal anoxia. J. Pediat.. 88: 851 (1976)

4. Dubowitz, L. M.. Dubowitz. U.. and Goldberg. ('.: Clinical assessment of gestational age in the newhorn infant. J. Pediat. 77: 1 (1970).

5. Guignard. J. P.. Torrade. A., Dat (unha, O.. and (iatier, E.: Glomerular filtration rate in the first three weeks of life. J. Pediat.. 87: 268 (1975)

6. Guignard. J. P.. Torrado, A.. Mazouni. S. M. and Gauticr. F.: Renal function in respiratory distress syndrome. J. Pediat., 88: 84.5 (1976).

7. Kagan. B. M. Stanincova, V.. Felix, N. S., Hodgman, J.. and Kalman. D. Body composition of premature infants: Relation to nutrition. Amer. J. (Clin. Nutr.. 2.5: $1153(1972)$.

8. Leake. R. D. Trygstad. $\left(\right.$. W.. and ()$h . W^{\prime}$. Inulin clearance in the newhorn infant: Relationship to gestational and postnatal age. Pediat. Res.. 10: 754 (1976).

9. Leake. R. D.. Zakatuddin, S.. Trygstad. ( . W. Fu, P.. and ()h. W.: The effects of large volume intravenous fluid infusion on neonatal renal function. J. Pediat.. 89: 968 (1976)

10. Oh, W.. Oh, M. A., and lind. J.: Renal function and blood volume in newborn infants related to placental transfusion. Actat Patediat. Scand.. 56: $107(1966)$

11. Robillard. J. E... Kulvinskas, (C.. Scssions, ( ... Burmeister, 1... and Smith. F. (i.: Maturational changes in the fetal glomerular filtration rate. Amer. $J$ Obstet Ciynecol. 122: 601 (1975).

12. Roc, J. H. Fepstein. J. H., and Goldstein. N. P.: A photemetric method for the determination of inulin in plasma and urine. J. Biol. (hem., /78: 8.39 (1949).

13. Requests for reprints should be addressed to: R. D. L.eake. M.D., Depart ment of Pediatrics, Harbor General Hospital, $1000 \mathrm{~W}$. Carson St. Torrance, (alif. 90509 (USA).

14. Received for publication July 19.1976

15. Accepted for publication February 15. 1977
Energy homeostasis glucagon glucose insulin neonate somatostatin

\title{
Effects of Somatostatin (SRIF) Infusion on Glucose Homeostasis in Newborn Lambs: Evidence for a Significant Role of Glucagon
}

\author{
MARK A. SPERLING, I.UIZ (iRAJWER, ROSEMARY D. L.EAKE. AND DFI.BERT A. FISHER
}

Deparme'nt of Pediatrics, L/CI.A-Harbor Cieneral Hospital, Torrance. C'aliformia. USA

\section{Summary}

In order to investigate the significance and relative contribution of glucagon (IRG) and insulin (IRI) to neonatal glucose homeostasis, studies were conducted utilizing somatostatin (SRIF) in newborn fasting lambs aged 1-3 days. A priming dose followed by constant infusion of SRIF was maintained for $2 \mathrm{hr}$. During the first hour, SRIF alone was infused (period A); during the second hour, glucagon or insulin were additionally infused (period $\mathrm{B})$; recovery was assessed $30 \mathrm{~min}$ after cessation of infusions (period $C$ ). During period $A$, a rapid and sustained suppression in the plasma concentrations of IRG and IRI occurred $(P<0.01)$, accompanied by a fall in plasma glucose significant at $60 \mathrm{~min}$. Reinfusion of glucagon $(5 \mathrm{ng} / \mathrm{kg} / \mathrm{min})$ during period $B$ raised IRG by $342 \pm 92 \mathrm{pg} / \mathrm{ml}$ (mean $\pm S E M, P$ $<0.01$ ). Despite ongoing SRIF, plasma IRI also rose by $19.7 \pm$ $7 \mu \mathrm{U} / \mathrm{ml}(P<0.05)$ and was not accountable by contamination of the infused glucagon with insulin. Plasma glucose rose modestly, perhaps as a result of the antagonistic effects of glucagon and insulin. After cessation of SRIF and glucagon infusions (period C) plasma IRG fell, plasma IRI rose, and plasma glucose fell significantly $(16.5 \pm 4 \mathrm{mg} / \mathrm{dl}, P<0.01)$. When insulin (0.1 units/kg/hr) was infused in period $B$, plasma IRI rose to approximately $70 \mu \mathrm{U} / \mathrm{ml}$, plasma IRG remained suppressed and plasma glucose fell profoundly, recovering during period $C$ as plasma IRI fell and plasma IRG rose. When, during period B, glucagon was infused at 10 times the original dose, plasma glucose concentration doubled despite a plasma IRI concentration of 100 $\mu \mathrm{U} / \mathbf{m l}$.

These results demonstrate that: (1) SRIF effectively inhibits IRI and IRG secretion in newborn lambs; (2) glucose falls when both hormones are acutely suppressed, suggesting that glucagon is a major hormone for maintaining blood glucose concentration during short term fasting; a rise in glucose, as occurs in insulindeficient diabetes, would be expected if insulin were the dominant hormone; (3) both insulin and glucagon and acute changes in the effective ratio of these hormones modulate glucose homeostasis; and (4) at physiologic concentrations glucagon can overcome the suppressive effects of SRIF on insulin secretion in newborn lambs.

\section{Speculation}

In the lamb, insulin and glucagon are both important for neonatal glucose homeostasis. Acute changes in the ratio of these two hormones can effectively modulate plasma glucose concentration presumably through governing hepatic glucose output and/or peripheral glucose utilization. Extrapolation, 